\title{
Development \& Testing of Industrial Scale, Coal Fired Combustion System, Phase 3
}

\author{
Quarterly Report \\ October 1 - December 31, 1997
}

\author{
By \\ Bert Zauderer
}

Work Performed Under Contract No.: DE-AC22-91PC91162

\author{
For \\ U.S. Department of Energy \\ Office of Fossil Energy \\ Federal Energy Technology Center \\ P.O. Box 880 \\ Morgantown, West Virginia 26507-0880 \\ By \\ Coal Tech Corp. \\ P. O. Box 154 \\ Merion Station, Pennsylvania 19066
}




\section{Disclaimer}

This report was prepared as an account of work sponsored by an agency of the United States Government. Neither the United States Government nor any agency thereof, nor any of their employees, makes any warranty, express or implied, or assumes any legal liability or responsibility for the accuracy, completeness, or usefulness of any information, apparatus, product, or process disclosed, or represents that its use would not infringe privately owned rights. Reference herein to any specific commercial product, process, or service by trade

name, trademark, manufacturer, or otherwise does not necessarily constitute or imply its endorsement, recommendation, or favoring by the United States Government or any agency thereof. The views and opinions of authors expressed herein do not necessarily state or reflect those of the United States Government or any agency thereof. 

Project: " DEVELOPMENT \& TESTING OF INDUSTRIAL SCALE,
COAL FIRED COMBUSTION SYSTEM,PHASE 3"

Contract: DE-AC22-91PC91162 --24

Contract Period of Performance: 9/30/91 to 9/30/98

Twenty FourthTechnical Progress Report

Period Covered by Report: October 1,1997 to December 31,1997

Contractor: Coal Tech Corp.

P.O.Box 154, Merion Station, PA 19066

Principal Investigator: Dr.Bert Zauderer, $\quad$ Phone No.(610) 667-0442

Date Submitted: January 17,1998

Prepared for

FETC Project Manager: Arun Bose

Federal Energy Technology Center

U.S.Department of Energy

P.O.Box 10940

Pittsburgh,PA 15236 


\begin{abstract}
In the fourth quarter of calendar year 1997, 11 days of tests on the $20 \mathrm{MMBtu} / \mathrm{hr}$ combustor-boiler facility were performed as part of a parallel project on sulfur capture in slag. No work was performed on the present project in this quarter. The total test days on the Philadelphia facility to the end of December 1997 was 103, of which 30 tests were part of the other DOE project. This exceeds the planned 63 test days for this project. All key project objectives have been exceeded including combustor durability, automated combustor operation, $\mathrm{NO}_{\mathrm{x}}$ emissions as low as $0.07 \mathrm{lb} / \mathrm{MMBtu}$ and $\mathrm{SO}_{2}$ emissions as low as $0.2 \mathrm{lb} / \mathrm{MMBtu}$. In addition, a novel postcombustion NOx control process has been tested on a $37 \mathrm{MW}$ and $100 \mathrm{MW}$ utility boiler. Any further tests will depend on the results of evaluations of current and prior tests. The only effort remaining on this project is facility disassembly and Final Report. This report also contains clarification of project results reported in the $22^{\text {nd }}$ Quarterly Technical Report in response to comments by DOE.
\end{abstract}




\section{TABLE OF CONTENTS}

ABSTRACT

PAGE

ii

1. EXECUTIVE SUMMARY 1

2. RESULTS AND DISCUSSION 2

2.1. PROJECT DESCRIPTION 2

2.1.1. Objectives

2

2.1.2. Technical Approach

2

2.1.2.1. Overview of the Work

2.1.2.2. Task Description

2

4

2.2. PROJECT STATUS

6

2.2.1. Task 5: Site Demonstration

6

2.2.2. Comment of the $22^{\text {nd }}$ Quarterly Technical Report

3. CONCLUSIONS

9 


\section{EXECUTIVE SUMMARY}

In the fourth quarter of calendar year 1997, 11 days of tests on the $20 \mathrm{MMBtu} / \mathrm{hr}$ combustor-boiler facility were performed as part of a parallel project on sulfur capture in slag. No work was performed on the present project in this quarter. The total test days on the Philadelphia facility to the end of December 1997 was 103, of which 30 tests were part of the other DOE project. This exceeds the planned 63 test days for this project. All key project objectives have been met or exceeded, including combustor durability, automated combustor operation, $\mathrm{NO}_{\mathrm{x}}$ emissions as low as $0.07 \mathrm{lb} / \mathrm{MMBtu}$ and $\mathrm{SO}_{2}$ emissions as low as $0.2 \mathrm{lb} / \mathrm{MMBtu}$. In addition, a novel post-combustion NOx control process has been tested on a 37 MW and 100 MW utility boiler. Any further tests will depend on the results of evaluations of current and prior tests. The only effort remaining on this project is facility disassembly and Final Report.

Section 3 of this report also contains clarification of project results reported in the $22^{\text {nd }}$ Quarterly Technical Report in responses to DOE questions and comments on that Report. The questions related primarily to the general and specific project objectives, and clarification of the procedures and results. The following are general comments concerning this matter:

One, the quarterly reports represent work in progress. Therefore, these reports are not complete, stand alone documents. In many cases, the results of tests performed in a specific quarter have not been evaluated, and no conclusions can be given. Section 2 of each quarterly report outlines the Contract's original overall project objectives and work statement. Any changes in the test effort are noted in Section 3 of each quarterly report that summarizes the work during that quarter. To provide additional clarification of the goals and objectives of this project, the specific performance accomplishments achieved to date will be compared in Section 3 of the present report with those stated in the original contract work statement.

Two, as stated in the DOE Contract: “ The goal of this project is to develop a coal fired slagging combustion system capable of being utilized with industrial scale boilers. Economic goals are to allow retrofit to existing boilers with a 4 year costs recovery when the price differential between coal-based fuels is $\$ 4.00$ per MMBtu (or less).” Such high differentials have not existed in over a decade. Currently, the differential between bituminous coal at the mine, which is about $\$ 20 /$ ton $(\$ 0.8 / \mathrm{MMBtu})$, and natural gas $(\$ 2 / \mathrm{Mmtu})$ is a little over $\$ 1 / \mathrm{MMBtu}$. Consequently, Coal Tech's goal for the current Demonstration Task 5 has been to design a second generation, 20 MMBtu/hr combustor-boiler system that is economical at a $\$ 1 / M M B t u$ oil/gas to coal price differential. To achieve this goal, various alternate components that reduce costs have been designed and tested at the Philadelphia facility. Since this an ongoing process and the potential commercial value of some of these designs is not finalized, only a general descriptions of the results have been given, without details of the design. 


\section{RESULTS AND DISCUSSION}

\subsection{PROJECT DESCRIPTION}

\subsubsection{Objectives}

The primary objective of the present Phase 3 effort is to perform the final testing, at a 20 $\mathrm{MMBtu} / \mathrm{hr}$ commercial scale, of an air cooled, slagging coal combustor for application to industrial steam boilers and power plants. The focus of the test effort is on combustor durability, automatic control of the combustor's operation, and optimum environmental control of emissions inside the combustor. In connection with the latter, the goal is to achieve $0.4 \mathrm{lb} / \mathrm{MMBtu}$ of $\mathrm{SO}_{2}$ emissions, $0.2 \mathrm{lb} . / \mathrm{MMBtu}$ of NOx emissions, and $0.02 \mathrm{lb}$. particulates/MMBtu. To meet the particulate goal a baghouse is used to augment the slag retention in the combustor. The NOx emission goal requires a modest improvement over maximum reduction achieved to date in the first generation combustor to a level of $0.26 \mathrm{lb}$./MMBtu. In the present second generation combustor, the best NOx levels with fuel rich conditions in the combustor was in the range of 0.3 to $0.4 \mathrm{lb} / \mathrm{MMBtu}$. To reach the $\mathrm{SO}_{2}$ emissions goal requires a combination of sorbent injection inside the combustor and sorbent injection inside the boiler, or stack.

The original plan was to meet the project objectives by a series of increasingly longer duration tests totaling up to 800 hours, with over 500 hours in the task 5 "Site Demonstration" effort. In the implementation of the first three project tasks, it was determined that this objective could met by daily cycling of the combustor in these three tasks, and by focusing the test effort on fuel flexibility and optimized combustion and environmental performance. Cycling without combustor refurbishment between cycles provides a more stringent test of combustor durability. In task 5, the steam output is also blown off. However, the option has been added to use the steam for process heat or steam turbine power generation if a means for generating revenue from this energy is developed during task 5. This last option was to be implemented after the completion of the required testing under the present project. At present this option does not appear to be likely.

The final objective was to define suitable commercial power or steam-generating systems to which the use of the air cooled combustor offers significant technical and economic benefits. In implementing this objective both simple steam generation and combined gas turbine-steam generation systems were considered.

\subsubsection{Technical Approach}

\subsubsection{Overview}

The work of this Phase 3 project is being implemented on Coal Tech's patented, 20 MMBtu/hr, air cooled cyclone coal combustor that is installed on an oil designed, package boiler. The task 2 and task 3 testing were performed at a manufacturing plant in Williamsport, PA, where this combustor was installed in 1987. The task 5 tests are being implemented at a site in Philadelphia, PA that was selected after the completion of the task 3 tests. The combustor has 
undergone development and demonstration testing since 1987. The primary fuel has been coal. Other tests, including combustion of refuse derived fuels and vitrification of fly ash, have been successfully performed.

The combustor's novel features are air cooling and internal control of $\mathrm{SO}_{2}, \mathrm{NOx}$, and particulates. Air cooling, which regenerates the heat losses in the combustor, results in a higher efficiency and more compact combustor than similar water-cooled combustors. Internal control of pollutants is accomplished by creating a high swirl in the combustor which traps most of the mineral matter injected in the combustor and converts it to a liquid slag that is removed from the floor of the combustor. $\mathrm{SO}_{2}$ is controlled by injecting calcium oxide based sorbents into the combustor to react with sulfur emitted during combustion. The spent sorbent is dissolved in the slag and removed with it, thereby encapsulating the sulfur in slag. Part of the sorbent exits the combustor with the combustion products into the boiler where it can react with the sulfur. The spent sorbent either deposits in the boiler or it is removed in the stack particle scrubber. NOx is controlled by staged, fuel rich combustion inside the combustor. Additional reductions are achievable by reburning in the boiler or by non-catalytic sorbent injection in the post-combustion gas zone. The latter procedure has been successfully implemented in 1997.

Excellent progress had been made prior to the start of the present project in meeting several of these combustor performance objectives. One of the most important objectives of this technology development effort was to demonstrate very high $\mathrm{SO}_{2}$ reduction in the combustor. Prior to the start of the present Phase 3 project, the peak $\mathrm{SO}_{2}$ reduction achieved with sorbent injection in the combustor had been $56 \%$, (+/-) 5\%. Of this amount a maximum of $11 \%$ of the total coal sulfur was trapped in the slag. On the other hand, up to $81 \% \mathrm{SO}_{2}$ reduction has been measured with sorbent injection in the boiler immediately downstream of the combustor. Tests in the past several years have revealed the critical role played by optimum operating conditions in the $\mathrm{SO}_{2}$ reduction process. Specifically, combustor operation must be automatically controlled, and solids feed and air-solids mixing in the combustor must be optimized. Progress in both areas has been accomplished in the past 5 years by using a microcomputer to control the combustion process and by testing various methods of feeding and mixing the coal and sorbents. In the summer of 1992 , tests performed in a prior project indicated that in excess of $90 \% \mathrm{SO}_{2}$ reduction could be achieved by sorbent injection in the combustor. Recently, similar SO2 reductions have been obtained with low $(<2 \% \mathrm{~S})$ sulfur coal, as measured at the outlet of the stack gas baghouse. However, this result has as yet not been achieved with higher sulfur coals.

Combustor durability is an essential requirement for commercial utility of the combustor. Due to the aggressive nature of the combustion process and the need to utilize refractory materials inside the combustor to withstand the $3000 \mathrm{~F}$ gas temperatures, durability has been one of the key challenges in the development process. Here also the use of computer control has been the means whereby this problem is being solved. Since introduction of computer control seven years ago, the need for frequent refractory liner patching inside the combustor has been sharply reduced. The durability issue can be addressed by accumulating running time in daily cyclic operation without combustor refurbishment between runs. This approach has been used in the latter task 2 and task 3 effort. All tests between May 1 and December 2, 1993, consisting of 26 hours of operation in task 2 and 185 hours in task 3 , have been performed without significant internal combustor refurbish- 
ment. In the task 5 effort, 93 days of test operations have been implemented with only limited refractory wall patching.

The final project objective of designing the combustor into a viable industrial steam or power generating system was accomplished by detailed engineering analysis on the use of the combustor in one or more steam generating cycles. This effort included an assessment of the requirements for commercializing the combustor for several industrial applications. To assure commercialization of this technology, the final project task is being implemented in a system that duplicates a commercial prototype power plant utilizing the air-cooled coal combustor technology.

\subsubsection{Task Description}

Task 1: Design, Fabricate, and Integrate Components

This task consisted of component design, component fabrications, and component integration, and shakedown tests. The $20 \mathrm{MMBtu} / \mathrm{hr}$ combustor was modified to allow safe and environmentally compliant operation for periods of up to 100 hours. This task is complete.

\section{Task 2: Preliminary Systems Tests}

The modified combustor system underwent a series of one day parametric tests of total duration of up to 100 hours to validate the design changes introduced in task 1 , and to accomplish the project objectives and goals. This task is complete.

\section{Task 3. Proof of Concept Tests}

The durability of the combustor was studied in a series of tests of between 50 and 100 hours of accumulated operation with no combustor refurbishment between tests. The total test period was planned to be up to 200 hours. This task is complete.

Task 4. Economic Evaluation \& Commercialization Plan

The economics of one or at most two different industrial scale steam based cycles using the combustor was evaluated. A commercialization plan was developed for marketing the combustor in an industrial environment both in the US and overseas. This originally scheduled work on this task is complete. However, efforts are continuing to commercialize the technology.

\section{Task 5. Conduct Site Demonstration}

This task is the final test activity in the project. Its objective is to demonstrate the durability and hence the commercial readiness of the combustor for its intended industrial application(s). The effort consists of two sub-tasks. In the first one any changes required as a result of prior tests were made to the combustor. In the second one, a series of tests were to be performed with a total test time of 500 hours. For a number of reasons, this effort was implemented in single daily shift operation with minimal combustor refurbishment between tests. 
The 500 hours are thus equal to 63 days of single shift operation. As of the end of the present reporting period, 93 test days have been completed.

\section{Task 6. Decommissioning Test Facility}

The test facility will be removed from the boiler installation and disposed in accordance with required regulations. Due to continuing opportunities for this technology, Coal Tech is seeking resources to allow the facility to remain in place after the end of this project. 


\subsection{PROJECT STATUS.}

\subsubsection{Task 5. Site Demonstration}

In the fourth quarter of calendar year 1997, 11 days of tests on the $20 \mathrm{MMBtu} / \mathrm{hr}$ combustor-boiler facility were performed as part of a parallel project on sulfur capture in slag. No work was performed on the present project in this quarter. The total test days on the Philadelphia facility to the end of December 1997 was 103, of which 30 tests were part of the other DOE project. This exceeds the planned 63 test days for this project. All key project objectives have been met or exceeded, including combustor durability, automated combustor operation, $\mathrm{NO}_{\mathrm{x}}$ emissions as low as $0.07 \mathrm{lb} / \mathrm{MMBtu}$ and $\mathrm{SO}_{2}$ emissions as low as $0.2 \mathrm{lb} / \mathrm{MMBtu}$. In addition, a novel post-combustion NOx control process has been tested on a $37 \mathrm{MW}$ and $100 \mathrm{MW}$ utility boiler. Any further tests will depend on the results of evaluations of current and prior tests. The only effort remaining on this project is facility disassembly and Final Report.

\subsubsection{Comments on the $22^{\text {nd }}$ Technical Quarterly Report}

This Section contains clarification of project results reported in the $22^{\text {nd }}$ Quarterly Technical Report in response to DOE questions and comments on that Report. The questions related primarily to the general and specific project objectives, and clarification of the procedures and results. The following are general comments concerning this matter.

Comparison of Technical Accomplishment in the Project with the Goals Stated in the Original Project Contract:

The work statement to this project contained the following list of performance goals for the present $20 \mathrm{MMBtu} / \mathrm{hr}$ coal fired, slagging combustor: After each goal, the status in the task 5 effort (see Section 2 for task description), using the second generation $20 \mathrm{MMBtu} / \mathrm{hr}$ combustorboiler facility in Philadelphia, is given.

Primary Fuel: "Boiler-grind (i.e.70\%-200 mesh) pulverized coal, coal water slurry, dry, ultrafine coal.

Status: $70 \%$ to $80 \%-200$ mesh pulverized coal, ground off site, and delivered in 1 ton supersacks to Philadelphia has been used in all the tests. Also, brief tests were successfully implemented with 50\%-100 mesh coarse ground coal. 10 tons of coalwater slurry had been successfully fired in the original $20 \mathrm{MMBtu} / \mathrm{hr}$ combustor in Williamsport,PA, in 1987. This fuel is not economical. There is no need for ultrafine coal in the slagging combustor.

Secondary Fuel Capability:

Status: Gas and No.2 oil are used to preheat the combustor, and No.2 oil up to 10 MMBtu/hr has been cofired with coal. Also, several days of single shift tests with No.6 oil were performed in the Williamsport combustor. 
Turndown Ratio: At least 3 to 1

Status: The present $20 \mathrm{MMBtu} / \mathrm{hr}$ combustor has been fired with coal at rates from 8.5 to $16 \mathrm{MMBtu} / \mathrm{hr}$. With gas only, firing rates start regularly at $1 \mathrm{MMBtu} / \mathrm{hr}$. Most operations are in the 15 to $17 \mathrm{MMBtu} / \mathrm{hr}$ heat input ranges. Higher inputs are at present limited by boiler safety and coal feed capacity limitations. The 17,500 lb/hr, 20 $\mathrm{MMBtu} / \mathrm{hr}$, saturated steam boiler is 27 years old, and it was designed for oil/gas.

Final Emissions: SO2 $<1.2 \mathrm{lb} / \mathrm{MMBtu}, \mathrm{NOx}<0.6 \mathrm{lb} / \mathrm{MMBtu}$, Particulates $<0.03$ lb/MMBtu. These goals were set on the basis of the technology in 1990. For ultimate commercial acceptance, DOE suggested goals equal to fuel oil fired units, viz,: $\mathrm{SO} 2<0.4 \mathrm{lb} / \mathrm{MMBtu}, \mathrm{NOx}<0.2 \mathrm{lb} / \mathrm{MMBtu}$, Particulates $<0.02$

Status of SO2: Tests were conducted in task 5 with coals ranging from $0.42 \% \mathrm{~S}$ Indian coal to $1.5 \%$ and $2.5 \% \mathrm{~S}$, US Bituminous coal. The results depend on many factors, only some of which are given here. The measurement results shown here were taken downstream of the baghouse.

-With the Indian coal, SO2 emissions were reduced by $50 \%$ to $\underline{\mathbf{0 . 5}} \mathbf{~ l b / M M B t u}$ with calcium oxide sorbent injection into the combustor.

-With $1.5 \% \mathrm{~S}$ coal, coarse calcium oxide sorbent injection into the combustor at a $\mathrm{Ca} / \mathrm{S}=2$, and fine calcium oxide injection into the combustor at a $\mathrm{Ca} / \mathrm{S}=2.44, \mathrm{SO} 2$

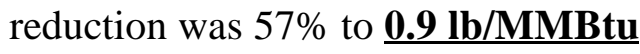

-With $1.5 \% \mathrm{~S}$ coal, and coarse calcium oxide sorbent injection into the combustor at a $\mathrm{Ca} / \mathrm{S}=1.81$, and fine calcium oxide injection into the boiler at $\mathrm{Ca} / \mathrm{S}=2.7, \mathrm{SO} 2$ reduction

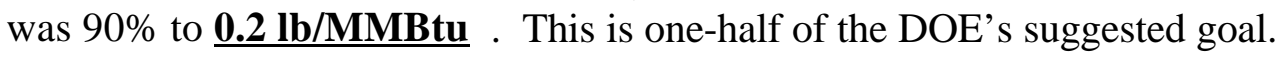
-Subsequent tests with higher sulfur coal, $2.5 \% \mathrm{~S}$, yielded lesser reductions. These later results are reported in the $23^{\text {rd }}$ Quarterly Report, for the period ending 9/30/97.

Status of NOx:

-With staged combustion at a fuel rich stoichiometric ratio, SR1, of $85 \%$ in the combustor, the NOx emission at the stack was measured at $0.44 \mathrm{lb} / \mathrm{MMBtu}$. -With the addition of Coal Tech's proprietary post combustion sorbent injection, the NOx emission at the stack was reduced to $\mathbf{0 . 0 7} \mathbf{~ l b / M M B t u}$. This value is less than one-half of the DOE suggested goal.

-With fuel lean combustion in the combustor, SR of 1.07, the NOx emission at the stack was $\mathbf{1 . 0 9} \mathrm{lb} / \mathrm{MMBtu}$.

-With the addition of Coal Tech's post combustion process, the NOx at the stack was reduced to $0.2 \mathrm{lb} / \mathrm{MMBtu}$.

These results were obtained by intermittent sampling at a fixed combustion gas condition. This condition was maintained at a steady condition for a sufficiently long period to allow multiple readings. A wide range of operating conditions was tested, and variations in test results were obtained. The above results are representative of the best results obtained.

Status of Particulates: The baghouse in the stack gas outlet of the $20 \mathrm{MMBtu} / \mathrm{hr}$ 
combustor is guaranteed to yield less than $0.03 \mathrm{lb} / \mathrm{MMBtu}$ by the manufacturer. One test with EPA Method 5 stack gas sampling was performed in February 1997 by a stack gas sampling company. The result yielded substantially higher particulates. An internal inspection of the baghouse and stack ducting showed extensive internal rusting of the wall and loose metal chips. Since the stack plume was totally clear, the higher particulate results were most probably due to these metal chips. Since the combustor removes about two-thirds to three-quarters of the coal ash as slag, dust loading on the stack is less than conventional pulverized coal fired boilers. Therefore, achieving the goal of particulate control to at least $0.02 \mathrm{lb} / \mathrm{MMBtu}$ is achievable in a properly fabricated baghouse.

Economics: Allow cost recovery of the retrofit of a slagging combustor in less than 4 years, when the oil-coal price differential is $\$ 4 / \mathrm{MMBtu}$ or less. Retrofit means that the original boiler, and other downstream components, such as turbo-generator units are already on site at the power plant.

Status of the Economic Studies: \$4/MMBtu oil/gas-coal cost differentials have not existed in over a decade. Currently, the differential between bituminous coal at the mine, which is about \$20/ton (\$0.8/MMBtu), and natural gas (\$2/MMBtu) is a little over \$1/MMBtu. Consequently, Coal Tech's goal for the current Demonstration Task 5 has been to design the $20 \mathrm{MMBtu} / \mathrm{hr}$ combustor-boiler system that is economical at a $\$ 1 / \mathrm{MMBtu}$ oi/gas to coal differential. To achieve this goal, various alternate components that reduce costs have been designed and tested in the Philqadelphia facility. Since this an ongoing process and the potential commercial value of some of these designs is not finalized, only a general descriptions of the results have been given without details of the design.

In task 4 of this project, two $20 \mathrm{MW}$ power plants were designed. One was a combined cycle with a natural gas fired turbine cycle and a coal-fired steam turbine cycle. Its capital cost was estimated at $\$ 1,200$. While this was substantially lower that comparable coal fired systems, it was not a retrofit application, and it would not meet the rapid payback goal for this project. The second application was a retrofit. A $20 \mathrm{MW}$ steam turbine generator system with all required power components at an existing power plant that had extensive supplies of coalmine waste was retrofitted with a sllaging combustion plant. The retrofit contained fuel storage and feed, slagging combustors, a boiler, and stack cleanup equipment. The original cost estimate was $\$ 850 / \mathrm{kw}$, which was subsequently reduced to $\$ 480 / \mathrm{kw}$. However, even this lower cost requires 10 years and a $\$ 2 / \mathrm{MMbtu}$ coal mine waste-oil/gas differential to obtain an acceptable rate of return of $20 \%$.

These results which were obtained prior to the start of task 5 in 1994, were used to design the present second generation $20 \mathrm{MMBtu} / \mathrm{hr}$ combustion system. The focus was on sharply reducing the cost of the entire combustion system including the combustor-boiler and all auxiliary components. Considerable progress has been made in reducing the capital and operating costs. This in turn has lead to new approaches to marketing this technology, with a focus on overseas markets. 
Goal of the Task 5 Testing: The primary purpose of this task was utilize the results of the previous four tasks to design a second generation, slagging combustor system, and to perform endurance testing on this system. Endurance was defined as 500 hours of operation to validate the durability of the combustor. Environmental performance was a secondary objective. Since the project resources did not allow round the clock operation, the 500 hour period was divided into single shift days of operation for a total of 63 days. Since every time the combustor is operated its durability is tested, operating time on other projects that use the $20 \mathrm{MMBtu} / \mathrm{hr}$ contribute to its durability. For this reason, time on the parallel DOE project is counted in the total operating time, while its number of days of testing is also reported separately.

\section{Other Clarifications on the $22^{\text {nd }}$ Quarterly Report:}

The objective of the $100 \mathrm{MW}$ utility boiler test was to determine if post combustion NOx control process tested in the $20 \mathrm{MMBtu} / \mathrm{hr}$ combustor facility could be scaled up by actor of 100 to a utility boiler. The measure of success was the durability of the equipment used to introduce the sorbent into the combustion gas stream, and to compare the NOx reduction, if any, with that obtained in other non-catalytic NOx reduction processes. The latter generally report about $1 / 3$ NOx reductions. In the June 1997 test, only a single process injector was used, while for maximum NOx reduction in a $100 \mathrm{MW}$ boiler, multiple injectors are needed. On that basis, the $25 \%$ NOx reduction obtained in the June 1997 test on the 100 MW boiler was a success.

A question was raised on the means by which off-site pulverized coal is loaded into the 4 ton pulverized coal bin. Specifically, why was the coal loaded pneumatically instead of dropping the coal though the bottom outlet of the supersack into the coal storage bin? That option was considered. However, the coal bin inlet is 24 feet above ground level. The cost of constructing a gantry crane system and moving the supersacks from the delivery truck to the crane, combined with the increased labor required to implement this and the increased safety concerns, far outweigh the simplicity and cost of the pneumatic system developed by Coal Tech.

Finally, there was a question of the impact of ash injection on the combustion system. Ash injection was mentioned on page 9 of the $22^{\text {nd }}$ quarterly report. Coal fly ash injection obtained from a utility power plant was injected into the prior $20 \mathrm{MMBtu} / \mathrm{hr}$ combustor in Williamsport. That work was for a project that preceded the current project. This fly ash consisted of over $97 \%$ metal oxides, with the balance unburned carbon. No further oxidization was noted in those tests. Fly ash injection was not attempted in the present project because the retention of the sub-10 micron fly ash particles in the combustor is very low.

\section{CONCLUSIONS}

All the objectives of task 5 of the present project have been met or exceeded, including duration of testing, 103 days versus 63 days; SO2 and NOx performance, $0.2 \mathrm{lb} / \mathrm{MMBtu}$ and 0.07 $\mathrm{lb} / \mathrm{MMBtu}$, respectively; and low cost combustor system designs. With the exception of some additional tests that may be implemented as data evaluation proceeds, the only remaining tasks are disassembly of the facility and the Final Report. 